\title{
The COVID-19 Pandemic: How Does it Affect Pregnant Women?
}

\author{
Arlina Dewi $^{1 *}$ (D) , Triantoro Safaria ${ }^{2}$, Supriyatiningsih Wenang ${ }^{3}$ D, Iwan Dewanto ${ }^{4}$, Alfun Dhiya An $^{3}$ (D) Dyah $_{\text {Tri Kusuma Dewi }}{ }^{10}$ \\ ${ }^{1}$ Department of Public Health, Master of Hospital Administration, Postgraduate Studies, Universitas Muhammadiyah Yogyakarta, \\ Bantul, Indonesia; '2Department of Psychology, Faculty of Psychology, Universitas Ahmad Dahlan, Yogyakarta, Indonesia; \\ ${ }^{3}$ Department of Obstetrics and Gynecology, Faculty of Medicine and Health Sciences, Universitas Muhammadiyah Yogyakarta, \\ Bantul, Indonesia; ${ }^{4}$ Department of Dentistry, Faculty of Medical and Health Science, Universitas Muhammadiyah Yogyakarta, \\ Bantul, Indonesia
}

Edited by: Ksenija Bogoeva-Kostovska Citation: Dewi A, Safaria T, Wenang S, Dewanto I, An AD, Pregnant Women? Open Access Maced J Med Sci. 2022 Jan 02; 9(T5):60-69. https://doi.org/10.3889/oamjms.2022.7838 Keywords: Anxiety; Information; Spiritual; Economy *Correspondence: Arlina Dewi, Department of Public Health, Master of Hospital Administration, Postgraduate Studies, Universitas Muhammadiyah Yogyakarta, E-mail: arlinadewi@umy.ac.id Received: 06-Nov-2021 Revised: 29-Nov-2021 Accepted: 12-Dec-2021 Copyright: $\odot 2022$ Arlina Dewi Triantoro Safaria Supriyatiningsih Wenang, Iwan Dewanto, Alfun Dhiya An Dyah Tri Kusuma Dew Funding: This study was supported by the Publication and Community Service Research Institute (LP3M) Universitas Muhammadiyah Yogyakarta
Competing Interests: The authors have declared Competing interests: The authors have declared that $n$ Open Access: This is an open-access article distributed under the terms of the Creative Commons AttributionNonCommercial 4.0 International License (CC BY-NC 4.0)

\begin{abstract}
BACKGROUND: The COVID-19 pandemic has a severe impact globally, not limited to general health and mental health. Pregnant women are a vulnerable group. Hormonal changes that occur during pregnancy significantly affect
\end{abstract} physical and psychological health.

AIM: The purpose of this study was to explore the anxiety felt by pregnant women holistically about their pregnancy during the COVID-19 pandemic.

METHODOLOGY: This study is qualitative phenomenological research with a naturalistic approach. The informants consisted of 20 pregnant women from three different islands and provinces in Indonesia in February 2021. They were selected to obtain heterogeneous data based on education level, gestational age, urban-rural areas, culture, and religion. The collection of information data used semi-structured interview guidelines with 12 questions. Data analysis used qualitative content analysis to explore pregnant women's anxiety with a similar meaning using software (Nvivo release 12)

RESULTS: Five domains caused anxiety for pregnant women related to the COVID-19 pandemic, such as feeling worried about being infected with COVID-19, the impact on health during pregnancy, the family economy, the circulating information around the community, and unfulfilled spiritual needs in utilizing places of worship.

CONCLUSION: The COVID-19 pandemic influenced pregnant women in a bio-psycho-socio-cultural manner, both about themselves, their fetuses, and their families. Anxiety that mothers feel during the pregnancy process needs proper treatment to protect the mothers' health and babies' well-being in the future. Thus, early detection or screening of anxiety during the COVID-19 pandemic in health services is necessary.

\section{Introduction}

The COVID-19 pandemic has a severe impact globally, not limited to general health but also mental health [1]. The high cases of patients infected with COVID-19 improve the symptoms of depression and anxiety. Particular populations are more vulnerable if mental health worsens during a pandemic COVID-19 [2], [3]. Brooks et al. mentioned that pregnant women belong to the population groups susceptible to infection [4], [5]. During pregnancy, a woman experiences physiological and hormonal changes that decrease maternal immunity, making them prone to virus infection [6], [7]. Trifu et al. explained that hormonal changes during pregnancy could resemble hyperthyroidism and pituitary adenoma [8]. It is because of the steroid hormone imbalance and their cortisol reactivity which is potentially harmful to maternal mental health [9]. This condition makes the process of pregnancy significantly affects physical and psychological health.

During the COVID-19 pandemic, Indonesia became one of the $18^{\text {th }}$ highest countries, with an infected population reaching 1,989,909 cases [10], [11]. Therefore, pregnant women tend to feel more afraid and anxious about their health given easily infected infectious diseases [7]. Mortazavi et al. stated that pregnant women experienced a 6 -fold increase in fear of COVID-19 [12]. The results of other studies explained that pregnant women experienced clinical anxiety with varying levels (severe to very severe), pressure during the COVID-19 pandemic, especially in Indonesia, reaching 63-68\% [13], [14], [15], [16].

The leading causes of anxiety in pregnant women are not limited to pregnant women themselves. Still, the health conditions of newborns increase anxiety by up to $86 \%$ if they experience developmental disorders, birth trauma (70.2\%), and the newborn's ability to breathe for the $1^{\text {st }}$ time $(62.5 \%)$ [17]. Research facts during the COVID-19 pandemic revealed that pregnant women would experience increased anxiety, fear, and stress about their safety during pregnancy and the fetus [18].

Exposure to high levels of stress or anxiety during pregnancy can be harmful to the mother's mental 
and physical health and the cognitive and emotional development of the child in the future [9], [19]. The results of this study indicated that anxiety during pregnancy affected the fetus, resulting in stunted intrauterine growth, premature birth, disability, intrauterine fetal death, neonatal death, and delayed development of requirements [20], [21], [22], [23]. Psychological disorders in pregnant women who are not appropriately handled affect the lives of mothers and children in the long term.

Preventive and promotive efforts to prevent the severe effects of anxiety on pregnant women during the COVID-19 pandemic need to be encouraged to minimize the risks posed by maintaining mental health during pregnancy. It is necessary to develop appropriate strategies to manage mental health during pregnancy during the COVID-19 pandemic [2], [24]. Health care providers and policymakers should give attention and support to pregnant women who experience anxiety at meeting counseling needs [12], [25]. Health care providers and policymakers should give attention and support to pregnant women who experience anxiety at meeting counseling needs. This study aims to explore the causes of the anxiety felt by pregnant women holistically during the COVID-19 pandemic.

\section{Methods}

\section{Study design}

This study used a qualitative phenomenological method with a naturalistic approach. It would explore the anxiety of pregnant women during the COVID-19 pandemic

\section{Sample selection}

The population of this study was pregnant women who were deliberately selected to explore their anxiety during the COVID-19 pandemic. The technique of determining the informants used purposive sampling to obtain heterogeneous information based on education level, gestational age, and geographical area, namely urban-rural, culture, and religion. The researchers chose informants when pregnant women did routine antenatal care checks at first-level health facilities even during the COVID-19 pandemic and were willing to participate in the research process. The informants in this study were 20 pregnant women from three different islands in Indonesia, namely Java $(n=9)$, Sumatra $(n=5)$, and Sulawesi $(n=6)$ in February 2021.

\section{Data collection}

The researchers collected data using in-depth-interview online interview techniques through
Google Meeting and Zoom Meeting to minimize direct interaction with pregnant women during the COVID-19 pandemic, which lasted for $1-1.5 \mathrm{~h}$ in regional languages to increase engagement between informants and interviewers. Each interview was attended by one interviewer (research team) and an informant. The researchers conducted in-depth interviews with three research assistants as a research team who previously received training in conducting interviews by experts to have the same perception in conducting interviews with pregnant women.

At the beginning of the in-depth interview, the informant introduced herself by mentioning the name, pregnancy condition (gestational age, parity, and complaints experienced by the informant in early pregnancy). In addition, the research team ensured the confidentiality of informant data and asked for consent for interviews with duration of between 1 and $1.5 \mathrm{~h}$ and video recording during the interview process. This step aimed to see the informants' facial expressions during the interview process.

The in-depth interview process of this research used a semi-structured interview guide with 12 biopsycho-social-spiritual-cultural questions, which had been discussed with psychologists and obstetricians. One of the questions the research team asked the informants was, "How do you feel about this pregnancy, especially during this COVID-19 pandemic?" After completing the interview, the research team transcribed it into Indonesian and translated it into English by a linguist. Since most informants used the local language, the researchers quoted the sentences to get similar ideas in different languages in this step.

\section{Data analysis}

This research data analysis used inductive content analysis to obtain new information about the causes of anxiety felt by pregnant women during the COVID-19 pandemic [26]. Data analysis in this study used software (Nvivo release 12) to perform coding and categorization [27]. The researchers coded by identifying the concepts implied in the transcript, then categorized them to form themes. A selection process became the next step to get an agreed theme and answer the researchers' questions (Table 1).

\section{Rigour of study}

The accuracy of naturalistic research has considered credibility, transferability, confirmability, and dependability [28]. The research team guaranteed the credibility of the data through accuracy in transcribing the recordings into transcripts used for direct quotations in informants' statements to strengthen the research results. In addition, the research process has been approved by the ethics committee of Universitas 'Aisyiyah Yogyakarta. The selected informants have met the inclusion criteria and agreed to be interviewed and recorded. The transcript 
Table 1: Summary of theme analysis

\begin{tabular}{|c|c|c|}
\hline Sample quotes & Items & Themes \\
\hline "I am afraid of getting infected. I am really afraid to check at PHC because & - General patients using the same health facilities & Feeling worried about being infected with \\
\hline there are random people there, some are elderly, some are children, some & - Pregnant women feeling vulnerable & COVID-19 while pregnant \\
\hline are teenagers like that. I do not know where they are from. even though & - Feeling worried about preparing a place for delivery & \\
\hline $\begin{array}{l}\text { they are being screened... but the people are too random, so I am still } \\
\text { afraid to go to PHC...." }\end{array}$ & - Health workers infected with COVID-19 & \\
\hline "If the people around me have coughs and colds, I am more worried. If I & - Feeling worried about symptoms & Feeling worried about the impact on health \\
\hline feel dizzy ... also worried, I have a little fever too worry...." & - Incurred mental health problems, "anxiety." & during pregnancy \\
\hline "In terms of financial problems, I already have savings. It is just the & - Decreased income & The impact of the COVID-19 pandemic on the \\
\hline savings, God willing; hopefully, it is enough for the birth. However, if there & - Needs during the childbirth process & family economy \\
\hline is anything... it is a bit difficult. Because my husband also sells it per day... & - Minimizing family expenses & \\
\hline Our income has decreased drastically". & - Utilizing Health insurance for childbirth & \\
\hline $\begin{array}{l}\text { "There is more fear. Yesterday, there was socialization from a village where } \\
\text { some were already infected, but I heard rumors. That is the head of the }\end{array}$ & $\begin{array}{l}\text { - The issue of pregnant women and health workers infected } \\
\text { with COVID-19 }\end{array}$ & Circulating information around the community \\
\hline Socioman Health Center... only two are said to be quarantined." & $\begin{array}{l}\text { - Health promotion, especially pregnancy during a } \\
\text { pandemic }\end{array}$ & \\
\hline "... the biggest thing is... anxiety about how to get out of the house. & - Getting closer to God & Unfulfilled spiritual needs in utilizing places of \\
\hline
\end{tabular}

results in verbatim form were analyzed using software to obtain themes in answering research questions.

In the transferability stage, in-depth interviews were conducted on informants from three different islands by considering heterogeneous data based on education level, gestational age, geographic area, namely urbanrural, culture, and religion. In addition, during the in-depth interview process, they used their respective regional languages to increase friendliness and engagement in communication, allowing informants to express their opinions regarding the anxiety during the COVID-19 pandemic. At the confirmation stage, the researchers continued to confirm based on the interpretation of the interview results with the researchers' understanding of the information presented by the informant. At this stage, the researchers demonstrated the data consistency with one of the research teams in coding the data, which was further confirmed by another research team to ensure the accuracy of the data. The research team also discussed the findings of the theme by providing that the final interpretation was reliable and valid.

\section{Ethical Consideration}

This research is part of the Muhammadiyah Maternal and Child Centre Research Program, Universitas Muhammadiyah Yogyakarta. Ethical approval was obtained from The Health Research Ethics Committee of Universitas 'Aisyiyah Yogyakarta (No.1362/KEP-UNISA/I/2021). Participation was entirely voluntary. As an incentive, participants receive refunds for internet packages.

\section{Results}

The results of an in-depth interview on 20 pregnant women in three islands (Java, Sumatra, and Sulawesi) during the COVID-19 pandemic showed that pregnant women experienced holistic anxiety both biopsycho-social-spiritual-cultural, five domains that caused anxiety for pregnant women, such as: feeling worried about being infected with COVID-19 while pregnant, the impact on health during pregnancy, the effect of the COVID-19 pandemic on the family economy, information circulating the community is disturbing, and unfulfilled spiritual needs in utilizing places of worship (Figure 1).

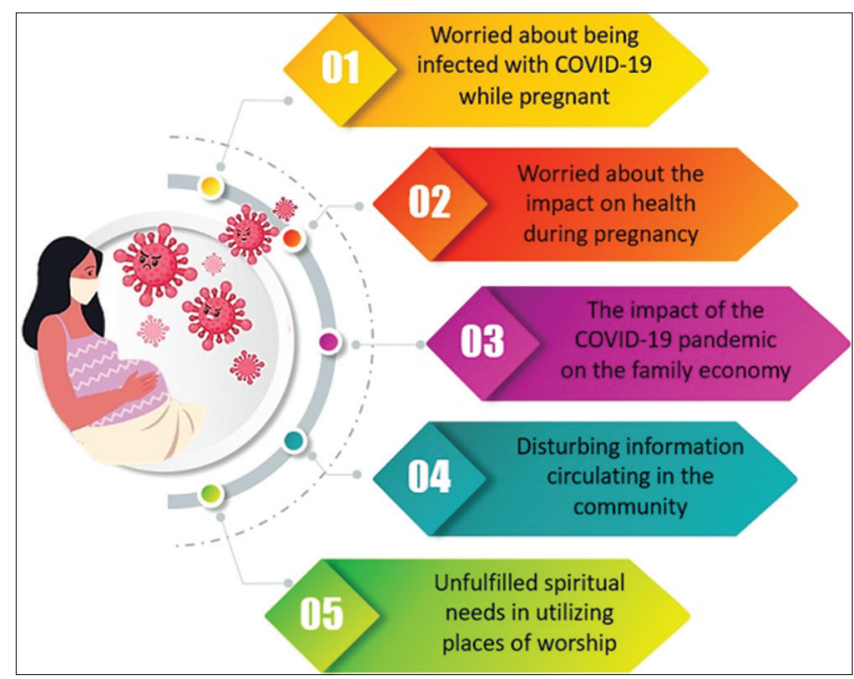

Figure 1: The cause of the anxiety felt by pregnant women during the pandemic COVID-19

Table 2 shows that most informants are 25-30 years old (65) with a college education (70). Most informants come from urban areas on Java (45), are Muslim (70). The informants have the same parity (primigravida or multigravida) with the highest gestational age in the $2^{\text {nd }}$ trimester (65). They have no comorbidities (90) and ANC check-up >4 (75) at the clinic or PHC (52.4). In addition, most of the informants had never experienced delivery (50\%), and $50 \%$ of the informants had experienced delivery either normally (80), cesarean section (10), and curettage (10).

\section{Worried about being infected with COVID-19 while pregnant}

During the COVID-19 pandemic, most people have anxiety if they will be infected. Pregnant women 
Table 2: Demographic characteristic of the informants

\begin{tabular}{|c|c|}
\hline Demographic informant & $n(\%)$ \\
\hline \multicolumn{2}{|l|}{ Age of pregnant women } \\
\hline$<25$ years & $1(5)$ \\
\hline $25-30$ years & $13(65)$ \\
\hline$>30$ years & $6(30)$ \\
\hline \multicolumn{2}{|l|}{ Education level } \\
\hline High school & $6(30)$ \\
\hline Collage & $14(70)$ \\
\hline \multicolumn{2}{|l|}{ Occupations } \\
\hline Does not work & $6(30)$ \\
\hline Work & $14(70)$ \\
\hline \multicolumn{2}{|l|}{ Geographic residence } \\
\hline Urban & $12(60)$ \\
\hline Rural & $8(40)$ \\
\hline \multicolumn{2}{|l|}{ Island } \\
\hline Java & $9(45)$ \\
\hline Sumatra & $5(25)$ \\
\hline Sulawesi & $6(30)$ \\
\hline \multicolumn{2}{|l|}{ Religion } \\
\hline Islam & $14(70)$ \\
\hline Non-Islam & $6(30)$ \\
\hline \multicolumn{2}{|l|}{ Parity } \\
\hline Primigravida & $10(50)$ \\
\hline Multigravida & $10(50)$ \\
\hline \multicolumn{2}{|l|}{ Gestational age } \\
\hline $1^{\text {st }}$ trimester & $1(5)$ \\
\hline $2^{\text {nd }}$ trimester & $13(65)$ \\
\hline $3^{\text {rd }}$ trimester & $6(30)$ \\
\hline \multicolumn{2}{|l|}{ Pregnancy comorbidities } \\
\hline There are comorbidities & $2(10)$ \\
\hline No comorbidities & $18(90)$ \\
\hline \multicolumn{2}{|l|}{ ANC check-up } \\
\hline$<4$ & $5(25)$ \\
\hline$>4$ & $15(75)$ \\
\hline \multicolumn{2}{|l|}{ ANC checkpoint } \\
\hline Clinic or PHC & $11(52.4)$ \\
\hline Independent practice doctor & $6(28.6)$ \\
\hline Hospital & $4(19.0)$ \\
\hline \multicolumn{2}{|l|}{ Pregnancy spacing } \\
\hline$<1$ year & $1(10)$ \\
\hline$>1$ year & $9(90)$ \\
\hline \multicolumn{2}{|l|}{ History of pregnancy } \\
\hline Abortion & $1(100)$ \\
\hline \multicolumn{2}{|l|}{ History of delivery } \\
\hline Normal & $8(80)$ \\
\hline Sectio Cesarea & $1(10)$ \\
\hline Curettage & $1(10)$ \\
\hline
\end{tabular}

also experience this condition because they are one of the at-risk populations. They are aware that pregnant women are vulnerable to being infected with COVID-19. One pregnant woman stated: "If I say... I am the most afraid, I am terrified. because it turns out that we cannot spend a lot on activities. Pregnant women are the ones who are vulnerable..." (Informant 7).

One informant said: "...While ouch.... pregnant women and the elderly are very vulnerable to corona... sometimes they are nervous. Oh..., how are we mentally? Our enemy is COVID. In addition, the corona is also increasing, and the black zone is also increasing. Not everyone cares about the corona, so I'm scared too because we're vulnerable. so scared" (Informant 11).

The main trigger that makes pregnant women feel worried, afraid, and anxious about being infected with COVID-19 is accessing health facilities, hospitals, $\mathrm{PHC}$, or clinics to conduct routine antenatal care visits. The anxiety felt by pregnant women is triggered because many general patients use health facilities. One informant said: ".... Actually. afraid because if you want to go to the hospital., afraid of crowds, afraid of infection.then avoid the hospital as much as possible..." (Informant 4).

The informant stated that: "...more afraid... if you go to PHC, there will be many people in PHC....
Yes, I am afraid of getting infected. I am really afraid to check at PHC because there are random people there, some are elderly, some are children, some are teenagers like that. I do not know where they are from. even though they are being screened... but the people are too random, so I am still afraid to go to PHC..." (Informant 6).

In addition, pregnant women are also worried if health workers (midwives and doctors) who provide antenatal care services in health facilities are infected with COVID-19. It becomes a cycle of transmission between health workers and pregnant women. One informant stated: "I am. worried, and it is time to go to the doctor. I hear many doctors have been infected.so I am afraid. so I must rethink for a pregnancy check" (Informant 16).

However, some pregnant women stated that they had to continue to do antenatal care at health facilities to find out the condition of their babies, even though it was not as routine as before the COVID-19 pandemic. "I am afraid that. for example, I want to consult.... or want to go to a clinic or PHC but.... if I do not consult a health worker. it will be worse..." (Informant 12).

Pregnant women said: "We are more afraid of not knowing the baby's condition. ...so we are afraid of the COVID too. But also afraid that the fetus is not in good condition... so in the end... we put the others aside, and the important thing is that we control it. We were afraid to meet other patients... use the same seat and the same room, but we are afraid... we do not know the baby's condition (Informant 7).

During this pandemic, pregnant women are confused and worried about planning and preparing for safe delivery. An informant stated: “... in this case... I am a bit worried about where to give birth.... Besides that, I am also a bit paranoid when I meet people. I am afraid" (Informant 1).

\section{pregnancy}

\section{Worried about the impact on health during}

The COVID-19 pandemic has caused people to experience excessive anxiety and worry especially pregnant women. The trigger is due to physical and hormonal changes so that the immune system decreases and is susceptible to disease. However, the impact of the pandemic on pregnant women is not limited to physical health but also mental health. Pregnant women said: "...if I focus more on psychology, because pregnant women have moods up and down, especially with the addition of COVID, it will be stressful..." (Informant 2).

In addition, pregnant women are worried if they show symptoms of being infected with COVID-19, such as dizziness, fever, and coughing runny nose. Pregnant women stated that: "... if the people around 
me have coughs and colds, I am more worried if I feel dizzy... also worried, have a little fever too worry..." (Informant 7).

Pregnant women said: ".... they (health worker) only measuring blood pressure in my hands... on pulses, then I have been said complaints that I have felt short of breath, but the nurse said ooh no asthma.... no further examination. I am scared...." (Informant 16).

The informant also stated that pregnant women are easily infected because of their physically weak body condition. As the informant said: "... actually, the fear is that the COVID pandemic. I am afraid of crowds of people, afraid of infection because it is said that pregnant women are more susceptible to viruses... because their immune system is lower..." (Informant 4).

The anxiety during the pandemic has caused pregnant women to worry about the condition of the fetus. One informant stated: "There is anxiety and fear between me and my fetus. I am terrified of being infected with COVID when I am pregnant. At this time, I do not know the risks during pregnancy." (Informant 15).

A pregnant woman said: “....anxiety...while pregnancy, I also think about how the baby will develop. Whether will it be affected later if exposed to COVID-19? Especially in this pandemic, afraid If I am exposed to COVID, I am afraid of miscarriage because it is still early in pregnancy..." (Informant 19).

During pregnancy, the informant who was infected with COVID-19 stated that: "I am most worried about what is in uteri if we can feel it. We do not know what is inside, and we are just afraid. We want to check with doctor ob-gyn, after finish quarantine...." (Informant 7).

\section{The impact of the COVID-19 pandemic on the family economy}

The COVID-19 pandemic has had a severe impact on society, especially in the economic sector. Some pregnant women and their families feel the effects of decreased income, salary cuts, and even rampant layoffs at the company to experience anxiety and worry about meeting their needs during pregnancy and postpartum. An informant said: "In terms of financial problems, I already have savings. It is just the savings, God willing; hopefully, it is enough for the birth. However, if there is anything... it is a bit difficult. Because my husband also sells it per day. our income has decreased drastically. This pandemic also makes it quiet..." (Informant 11).

"I am afraid that if I was laid off or dismissed, I was worried, but so far I have been praying a lot... so that it does not turn out like that..." (Informant 14).

This condition affects the mental health of pregnant women and their families, so that it becomes a quarrel because family needs are not met as before the COVID-19 pandemic. Here, the other members of families play a role in meeting the nutritional needs of pregnant women and limiting unnecessary expenses. The informant said: “...financial conditions are declining in the COVID pandemic.... Alhamdulillah, sometimes my extended family helps fulfill my nutrition with milk and vitamins. As for expenses, if it can be postponed, it will be postponed" (Informant 10).

In addition, most pregnant women who have a health insurance plan use health insurance (BPJS Kesehatan) to minimize expenses during delivery. One informant said: "I am trying to use health insurance. Indeed, this pandemic is a bit of financial difficulty. Maybe I will try to use health insurance (BPJS)" (Informant 6).

\section{Disturbing information circulating in the community}

The COVID-19 pandemic has led to the proliferation of various information circulating in the community, increasing the anxiety of pregnant women. Information spread through various social media, and public talk shows that many pregnant women were infected with COVID-19. The informant said: "I am afraid, if we are infected with the virus, maybe I have not heard from people. If I read articles, pregnant women are rarely infected. So every time you open social media, it does not appear too much if COVID infected pregnant women. There may be one... one... two who appear to be infected with COVID, just reading" (Informant 18).

In addition, information circulating in the community is that health workers who have finished assisting with childbirth or field health promotions that provide education to the community will be exposed. This situation makes pregnant women even more afraid and anxious in the face of the COVID-19 pandemic. An informant stated: "There is fear. Yesterday, there was socialization from a village where some were already infected, but I heard rumors. That is the head of the Socioman Health Center.... only two are said to be quarantined" (Informant 16).

To reduce anxiety, pregnant women take the initiative to minimize the consumption of information related to COVID-19 both through social media and conversations in the community. Pregnant women said: "If I reduce social media, which is not too important. Especially social media that are personal, such as friends' statuses, what are the statuses... other people are like that, news that is unsettling. I reduce it like that, so it is more like education" (Informant 2).

\section{Unfulfilled spiritual needs in utilizing places of worship}

The COVID-19 pandemic has made it difficult for people dan pregnant women to carry out activities 
outside the home freely. They will immediately feel worried and anxious once they have direct contact with COVID-19 sufferers, both symptomatic and asymptomatic. One of the efforts to reduce stress is to draw closer to God, the planner of human life and positive thinking. However, spiritual needs by utilizing places of worship cannot be carried out properly because of restrictions to avoid crowding. An informant said: "... the biggest thing is... anxiety about how to go out of the house. Whatever it is..., it means... going to a place of worship is a bit difficult..." (Informant 19).

Another informant said: "In this time of the pandemic because when someone is sick or exposed to COVID, they close places of worship.... Even if the church is opened, it is still according to the health protocol" (Informant 14).

Pregnant women realize that they are at risk, and only God is the place to ask for protection to keep them and the fetus healthy. The pandemic forces pregnant women to worship and meet their spiritual needs at home to minimize direct contact with other people. An informant stated that: "... I have heard a lot of religious sermons during this pregnancy. If you are pregnant, it is not just pregnant. You bet the lives of 2 people. You want to die or something..., so I feel yes too. Now I stand bay at home, so thank God there are lots of prayers... lots of prayers like that' (Informant 11).

An informant said: "If I worship alone, I still worship as usual. The difference is that I used to enjoy worshiping in church... just last week; it was opened, it is better to continue worshiping in church. When I heard that there was infected COVID... so when I went to the hospital, many people were sick. In the church, there were many people, but the anxiety was different" (Informant 14).

\section{Discussion}

The first finding in this study is that pregnant women are anxious about getting infected with COVID-19. Their concern is reasonable. Pregnant women are vulnerable to decreased body immunity and are susceptible to disease [6]. A study showed that $93 \%$ of pregnant women experience anxiety and stress about getting infected with COVID-19 [29]. Another study found that pregnant women feel afraid of being infected with COVID-19 and worry about the fetus'. Their level of anxiety would grow six times greater and two times more significant if their family members were infected [12], [18]. The second finding during this pandemic discovered that most pregnant women would feel anxious about their health due to various symptoms such as fever (68\%), cough $(34 \%)$, lymphocytopenia (59\%) with increased C-reactive protein (70\%). Up to $91 \%$ of pregnant women may have a cesarean section in labor [30].
Pregnant women's anxiety and fear make them reluctant to access health facilities. Mothers feel unsafe if they do antenatal care checks at health facilities that provide general care services. Moyer et al. stated in their research that $25.8 \%$ of pregnant women from 47 countries stopped routine antenatal care checks directly with health workers [18], [29]. The researchers also found that pregnant women find it hard to plan a place to give birth during this COVID-19 pandemic. In line with the research of Moyer et al., before the COVID-19 pandemic, most pregnant women had to plan delivery at a general hospital. Still, during this pandemic, pregnant women stated that they would deliver the baby at home or did not know where to plan delivery [29].

Pregnant women experience anxiety in accessing health facilities during the COVID-19 pandemic because health workers risk infection when providing patient care [31]. Celebi et al. explained that the positive rate of COVID-19 in health workers reached $3.4-8.3 \%$ because the health workers were not wearing masks, unsafe PPE, and failing to do social distancing [32]. Health workers must be aware that COVID-19 does not choose who will be infected, so caution is needed with strict application of health protocols in carrying out their duties and activities in general in society.

The government or policymakers of family health programs need to carry out various efforts to minimize anxiety caused by fears of pregnant women being infected with COVID-19 through the cooperation of health workers in all health facilities. It is important to remember that pregnant women's health is not limited to physical but also mental health [33]. Health workers and pregnant women must practice precautionary behavior against the risk of being exposed to COVID-19 in daily life with preventive measures [34]. Appropriate personal protective equipment and health protocols include washing hands, avoiding crowds, and maintaining social distance [32]. In particular, health workers should be provided with infection control training to reduce the risk of infection before delivering services. Specific exposures are associated with an increased risk and regular screening of health workers for early detection and isolation of infected health workers [31], [32].

In antenatal care health services, health workers can form internet-based social networking groups between pregnant women and health workers, aiming to provide education and advice for pregnant women during the COVID-19 pandemic. There should be close monitoring, especially for pregnant women with COVID-19, and the management of prevention, preparedness, rapid response, and restoration of the health of pregnant women [12], [30]. In addition, health facilities can provide virtual training classes, virtual counseling, and virtual birth preparation to improve the welfare and peace of pregnant women [12]. Other studies mentioned that giving psychological support, clarifying misconceptions regarding the risk 
of transmitting COVID-19 to the fetus, and advice on preventing transmission of the virus in the delivery route reduces pregnant women's psychological impact.

In special health services for maternitypregnancy care, the solution offered is health units with different routes from general patients. There should be special health workers who only serve pregnant women with strict health protocols to prevent exposure to COVID-19 from health workers pregnant women [18]. The New York-Presbyterian stated that only two companions for pregnant women (family and trained people) and restrictions on visits to avoid exposure to COVID-19 during labor and postpartum [35], [36]. America's Rescue Plan 2021 through the Safe Childbirth Act from COVID-19 has addressed maternal health issues by allowing loved ones to accompany individuals during pregnancy and childbirth care in hospitals, expanding access to remote healthcare and ensuring easy access to COVID tests, treatment, and vaccinations for pregnant women [37].

According to the third finding, pregnant women's anxiety during the pandemic also included the family economy. This condition makes pregnant women or their families lose their jobs, and their incomes drop drastically compared to before the pandemic. Mortazavi et al. stated that pregnant women experienced 3 times higher anxiety during a pandemic when family income was low and 1.5 times more likely to be laid off from work [12], [35], [38], [39]. The COVID-19 pandemic has impacted the economic sector, increasing community poverty from $17.1 \%$ to $25.9 \%$ and $90 \%$ of individuals without a job in the San Francisco area [40]. During this pandemic, the main focus of the government and world health institutions is to suppress cases of the COVID-19 pandemic with a lockdown strategy without considering the economy and public health, resulting in a decrease in economic activity that causes job losses and a reduction in public consumption. This issue also makes the economic recovery unpredictable [41], [42].

Efforts to prevent the community's economic decline during the COVID-19 pandemic can be overcome with fiscal policy, monetary policy, financial regulation policy, social security policy, industrial policy, and trade policy [42], [43]. Djalante et al. mentioned that fiscal simulation with the role of the private and financial sectors in supporting small-medium enterprises and decent work for the community is to revive the economic industry [44]. The results of other studies showed that the simulation in the Implementation of The Coronavirus Aid, Relief, and Economic Security Act, with the provision of benefits and compensation to the community, can cause a slight decrease in the poverty rate from $17.1 \%$ to $16.5 \%$ during the pandemic [40], [45].

The third fact is that pregnant women feel anxious about various disturbing information circulating in the community. Misleading information will affect the anxiety of pregnant women. In response to a crisis like the COVID-19 pandemic, pregnant women experience health anxiety, making it hard to get correct information. Women are also becoming increasingly anxious about their relatives, children, and unborn child due to their dread of the unknown [46].

The COVID-19 information for pregnant women may be found on YouTube videos, which are freely available. The present study revealed that videos concerning pregnancy and COVID-19 receive many views but that the quality and trustworthiness of the videos are typically poor [46]. Videos published by independent individuals are more likely than videos uploaded by government or news agencies to include false or misleading information. Educational videos from reliable sources such as universities and health organizations were scarce [47]. According to the data, in contrast to the tricky films in English, the misleading videos in Mandarin were more popular than the beneficial videos. Those misleading in Mandarin were longer in duration than practical videos, and they had a more significant number of views [48].

The information is a solution to reduce the anxiety of pregnant women related to COVID-19 information with effective communication of trusted mass media to prevent the spread of the virus from providing understanding to pregnant women and their families regarding the risk of COVID-19 [49]. In addition, the information offered to the public through social media must be helpful and provide comfort for the listeners [49]. When people have proper knowledge and understanding regarding COVID-19, they can consciously choose reliable information as a reference to minimize anxiety during the COVID-19 pandemic.

The fifth finding in the study is spiritual needs during the COVID-19 pandemic, which is challenging to use places of worship. During the pandemic, religious gatherings and closing worship facilities are temporarily suspended because they can become places of risk of disease transmission. Believers choose to worship in places of worship to communicate effectively with God in seeking peace and strength regarding the risk of COVID-19 [50]. Research in the UK explained that closing mosques are a dilemma because it sacrifices the sacred status of mosques and congregational worship or endangers the lives of thousands of Muslims [51]. Research in Malaysia found that 35\% of COVID-19 cases occurred after a Sri Petaling meeting, a Muslim organization [52]. This condition requires decision-making to prohibit mass worship by considering the benefits and disadvantages for the community in the era of the COVID-19 pandemic, as in the hadith narrated by Abu Hurairah that Islam is easy and no one complicates this religion.

In the UK, mosques or places of worship benefit the community by turning their functions into hospitals to help reduce COVID-19 cases [53]. According to health protocols with social distance, worship activities are carried out according to social distance. The congregation does not show symptoms and religious 
sermons by online-based spiritual experts [54]. Faith in God keeps us hopeful and feels protection to get a sense of security. The current situation makes people keep praying together or alone [55]. In line with the finding that most pregnant women continue to worship their own, pregnant women are more comfortable worshiping with the place of worship.

Religion plays an essential role in maintaining mental comfort and has a link in maintaining mental health. Strong faith can understand the meaning of an event and affect life, especially during the COVID-19 pandemic. Most Catholics (67.6\%) said that spirituality is essential in life because they feel safe and believe they are protected from the threat of the COVID-19 pandemic [55]. Koenig mentioned efforts to stay spiritually healthy during the COVID pandemic by studying religion such as praying to God, reading the holy book, reading prayers when taking medicine, and others. The role of religious practice can increase endurance. If infected with COVID-19, people will only have mild symptoms and get healthy faster [56].

The limitation of this research is that in-depth interviews were conducted online, so there were problems with the signal stability of the informants and interviewers, which caused some parts of the voice recording not to be adequately recorded. However, the interviewers still reconfirmed the information, which was not recorded properly.

\section{Conclusions}

The COVID-19 pandemic directly influences pregnant women in a bio-psycho-social-cultural and spiritual way, both for themselves, their fetuses, and their families. This condition requires screening for anxiety during a pandemic in health facilities and handling or solutions appropriately and quickly to not affect the health and well-being of the mother and fetus. Future research should develop the management of handling anxiety for pregnant women, especially during the COVID-19 pandemic, considering socio-culture in Indonesia.

\section{References}

1. Pawar M. The global impact of and responses to the COVID-19 pandemic. Int J Community Soc Dev. 2020;2:111-20. https://doi. org/10.1177/2516602620938542

2. Torales J, O'Higgins M, Castaldelli-Maia JM, Ventriglio A. The outbreak of COVID-19 coronavirus and its impact on global mental health. Int J Soc Psychiatry 2020;66:317-20. https://doi. org/10.1177/0020764020915212

PMid:32233719

3. Vindegaard N, Benros ME. COVID-19 pandemic and menta health consequences: Systematic review of the current evidence. Brain Behav Immun. 2020;89:531-42. https://doi. org/10.1016/j.bbi.2020.05.048

PMid:32485289

4. Brooks SK, Weston D, Greenberg N. Psychological impact of infectious disease outbreaks on pregnant women: Rapid evidence review. Public Health. 2020;189:26-36. https://doi. org/10.1016/j.puhe.2020.09.006

PMid:33142123

5. Schwartz DA, Graham AL. Potential maternal and infant outcomes from coronavirus 2019-nCoV (SARS-CoV-2) infecting pregnant women: Lessons from SARS, MERS, and other human coronavirus infections. Viruses. 2020;12:194. https://doi. org/10.3390/v12020194

PMid:32050635

6. Brooks A. Health Literacy: What is it and why is it Important? 2019. Available from: https://www.rasmussen.edu/degrees/ health-sciences/blog/importance-of-health-literacy [Last accessed on 2020 Dec 21].

7. Jamieson DJ, Theiler RN, Rasmussen SA. Emerging infections and pregnancy. Emerg Infect Dis 2006;12(11):1638-43. https:// doi.org/10.3201/eid1211.060152

PMid:17283611

8. Trifu S, Vladuti A, Popescu A. The neuroendocrinologica aspects of pregnancy and postpartum depression. Acta Endocrinol (Buchar). 2019;15:410-5. https://doi.org/10.4183/ aeb.2019.410

9. Kofman YB, Eng ZE, Busse D, Godkin S, Campos B, Sandman CA, et al. Cortisol reactivity and depressive symptoms in pregnancy: The moderating role of perceived social support and neuroticism. Biol Psychol. 2019;147:107656. https://doi. org/10.1016/j.biopsycho.2019.01.016

10. Johns Hopkins University. Coronavirus COVID-19 (2019-nCoV); 2021. Available from: https://www.arcgis.com/apps/dashboards/ bda7594740fd40299423467b48e9ecf6 [Last accessed on 2021 Jun 21].

11. Kementerian Kesehatan RI. Penyebaran Kasus Konfirmasi COVID-19 di Indonesia; 2021. Available from: https://www. kemkes.go.id/article/view/20012900002/Kesiapsiagaanmenghadapi-Infeksi-Novel-Coronavirus.html [Last accessed on 2021 Jun 21].

12. Mortazavi F, Mehrabadi M, KiaeeTabar R. Pregnant women's well-being and worry during the COVID-19 pandemic: A crosssectional study. BMC Pregnancy Childbirth. 2021;21:59. https:// doi.org/10.1186/s12884-021-03548-4 PMid:33451292

13. Corbett GA, Milne SJ, Hehir MP, Lindow SW, O'connell MP. Health anxiety and behavioral changes of pregnant women during the COVID-19 pandemic. Eur J Obstet Gynecol Reprod Biol 2020;249:96-7. https://doi.org/10.1016/j.ejogrb.2020.04.022

14. Lebel C, MacKinnon A, Bagshawe M, Tomfohr-Madsen L, Giesbrecht G. Elevated depression and anxiety symptoms among pregnant individuals during the COVID-19 pandemic. J Affect Disord 2020;277:5-13. https://doi.org/10.1016/j. jad.2020.07.126

15. Saccone G, Florio A, Aiello F, Venturella R, De Angelis MC, Locci M, et al. Psychological impact of coronavirus disease 2019 in pregnant women. Am J Obstet Gynecol. 2020;223(2):293-5. https://doi.org/10.1016/j.ajog.2020.05.003 PMid:32387321

16. Zainiyah Z, Susanti E. Anxiety in pregnant women during 
coronavirus (Covid-19) pandemic in East Java, Indonesia. Majalah Kedokteran Bandung. 2020;52:149-53. https://doi. org/10.15395/mkb.v52n3.2043

17. Deklava L, Lubina K, Circenis K, Sudraba V, Millere I. Causes of anxiety during pregnancy. Proc Soc Behav Sci. 2015;205:623-6. https://doi.org/10.1016/j.sbspro.2015.09.097

18. Sahin BM, Kabakci EN. The experiences of pregnant women during the COVID-19 pandemic in Turkey: A qualitative study. Women Birth. 2021;34(2):162-9. https://doi.org/10.1016/j. wombi.2020.09.022

PMid:33023829

19. Rathbone AL, Prescott J. Pregnancy-specific health anxiety: Symptom or diagnosis? Br J Midwifery. 2019;27:288-93. https:// doi.org/10.12968/bjom.2019.27.5.288

20. Bjelica A, Cetkovic N, Trninic-Pjevic A, Mladenovic-Segedi L. The phenomenon of pregnancy a psychological view. Ginekol Pol. 2018;89(2):102-6. https://doi.org/10.5603/GP.a2018.0017 PMid:29512815

21. Fischbein RL, Nicholas L, Kingsbury DM, Falletta LM, Baughman KR, VanGeest J. State anxiety in pregnancies affected by obstetric complications: A systematic review. J Affect Disord. 2019;257:214-40. https://doi.org/10.1016/j. jad.2019.07.007

PMid:31301626

22. Loomans $E M$, van Dijk AE, Vrijkotte $T G$, van Eijsden $M$, Stronks K, Gemke RJ, et al. Psychosocial stress during pregnancy is related to adverse birth outcomes: Results from a large multi-ethnic community-based birth cohort. Eur J Public. 2013;23(3):485-91. https://doi.org/10.1093/eurpub/cks097 PMid:22850187

23. Seyed Ahmadi Nejad FS, Golmakani N, Asghari Pour N, Taghi Shakeri M. Effect of progressive muscle relaxation on depression, anxiety, and stress of primigravid women. Evid Based Care. 2015;5:67-76. https://doi.org/10.22038/ebcj.2015.4093

24. Hamzehgardeshi Z, Omidvar S, Amoli AA, Firouzbakht M. Pregnancy-related anxiety and its associated factors during COVID-19 pandemic in Iranian pregnant women: A web-based cross-sectional study. BMC Pregnancy Childbirth. 2021;21:208. https://doi.org/10.1186/s12884-021-03694-9

25. Nanjundaswamy MH, Shiva L, Desai G, Desai G, Ganjekar S, Kishore $\mathrm{T}$, et al. COVID-19-related anxiety and concerns expressed by pregnant and postpartum women a survey among obstetricians. Arch Womens Ment Health. 2020;23:787-90. https://doi.org/10.1007/s00737-020-01060-w

26. Patton MQ. Qualitative Research and Evaluation Methods. $3^{\text {rd }}$ ed. Thousand Oaks, Calif: Sage Publications; 2002.

27. FlickU.TheSAGE Handbook of Qualitative DataAnalysis. Singapore: Sage Publications; 2014. Available from: http://93.174.95.29/main/ FE1319CEE12B198A237A00CDBA4CC74D [Last accessed on 2020 Apr 30].

28. Mclnnes S, Peters K, Bonney A, Halcomb E. An exemplar of naturalistic inquiry in general practice research. Nurse Res. 2017;24(3):36-41. https://doi.org/10.7748/nr.2017.e1509 PMid:28102791

29. Moyer CA, Compton SD, Kaselitz E, Muzik M. Pregnancyrelated anxiety during COVID-19: A nationwide survey of 2740 pregnant women. Arch Womens Ment Health. 2020;1-9. https:// doi.org/10.1007/s00737-020-01073-5

PMid:32989598

30. Zaigham M, Andersson O. Maternal and perinatal outcomes with COVID-19: A systematic review of 108 pregnancies. Acta Obstet Gynecol Scand. 2020;99(7):823-9. https://doi. org/10.1111/aogs.13867

PMid:32259279

31. Chou R, Dana T, Buckley DI, Selph S, Fu R, Totten AM.
Epidemiology of and risk factors for coronavirus infection in health care workers: A living rapid review. Ann Intern Med. 2020;173(2):120-36. https://doi.org/10.7326/M20-1632 PMid:32369541

32. Çelebi G, Pişkin N, Bekleviç AC, Altunay Y, Keleş AS, Tüz MA, et al. Specific risk factors for SARS-CoV-2 transmission among health care workers in a university hospital. Am J Infect Control. 2020;48(10):1225-30. https://doi.org/10.1016/j.ajic.2020.07.039 PMid:32771498

33. Puertas-Gonzalez JA, Mariño-Narvaez C, PeraltaRamirez MI, Romero-Gonzalez B. The psychological impact of the COVID-19 pandemic on pregnant women. Psychiatry Res. 2021;301:113978. https://doi.org/10.1016/j. psychres.2021.113978

PMid:34062321

34. Lee M, You M. Psychological and behavioral responses in South Korea during the early stages of coronavirus disease 2019 (COVID-19). Int J Environ Res Public Health. 2020;17:2977. https://doi.org/10.3390/ijerph17092977

PMid:32344809

35. Jelly P, Chadha L, Kaur N, Sharma S, Sharma R, Stephen S, et al. Impact of COVID-19 pandemic on the psychological status of pregnant women. Cureus. 2021;13(1):e12875. https://doi. org/10.7759/cureus. 12875

PMid:33633904

36. NewYork-Presbyterian. COVID-19 General Visitation Guidelines and Visitor Policy Changes New York Presbyterian; 2021. Available from: https://www.nyp.org/coronavirusinformation/coronavirus-visitor-policy-change [Last accessed on $2021 \mathrm{Jul}$ 05].

37. Bernstein A. Maternity, Maternal Health, and the Economy during the Pandemic. The Century Foundation; 2021. Available from: https://tcf.org/content/commentary/maternity-maternalhealth-economy-pandemic [Last accessed on $2021 \mathrm{Jul} 05]$.

38. Burki T. The indirect impact of COVID-19 on women. Lancet Infect Dis. 2020;20(8):904-5. https://doi.org/10.1016/ S1473-3099(20)30568-5

PMid:32738239

39. Lin TK, Law R, Beaman J, Foster DG. The impact of the COVID-19 pandemic on economic security and pregnancy intentions among people at risk of pregnancy. Contraception. 2021;103(6):380-5. https://doi.org/10.1016/j.contraception.2021.02.001 PMid:33587906

40. Martin A, Markhvida M, Hallegatte S, Walsh B. Socio-economic impacts of COVID-19 on household consumption and poverty. Econ Disaster Clim Chang. 2020;1-27. https://doi.org/10.1007/ s41885-020-00070-3

PMid:32838120

41. UNICEF. Direct and Indirect Effects of the COVID-19 Pandemic and Response in South Asia Nepal: UNICEF Regional Office for South Asia; 2021. Available from: https://www.unicef.org/rosa/ reports/direct-and-indirect-effects-covid-19-pandemic-andresponse-south-asia [Last accessed on 2021 Aug 10].

42. Varona L, Gonzales JR. Dynamics of the impact of COVID-19 on the economic activity of Peru. PLoS One 2021;16(1):e0244920. https://doi.org/10.1371/journal.pone.0244920 PMid:33417613

43. Michelsen C, Baldi G, Dany-Knedlik G. Global Economy: Slow Recovery Following Deep Recession: DIW Economic Outlook. DIW Weekly Report; 2020. Available from: https://ideas. repec.org/a/diw/diwdwr/dwr10-37-2.html [Last accessed on 2021 Jul 06].

44. Djalante R, Lassa J, Setiamarga D, Sudjatma A, Indrawan M, Haryanto $\mathrm{B}$, et al. Review and analysis of current responses to COVID-19 in Indonesia: Period of January to March 2020. 
Prog Disaster Sci. 2020;6:100091. https://doi.org/10.1016/j. pdisas.2020.100091

PMid:34171011

45. Mohsin A, Hongzhen L, Hossain SF. Impact of COVID-19 pandemic on consumer economy: Countermeasures analysis. SAGE Open. 2021;11:21582440211008876. https://doi. org/10.1177/21582440211008875

46. Yuksel B, Cakmak K. Healthcare information on YouTube: Pregnancy and COVID-19. Int J Gynecol Obstet. 2020;150(2):189-93. https://doi.org/10.1002/ijgo.13246 PMid:32471005

47. Bora K, Das D, Barman B, Borah P. Are internet videos useful sources of information during global public health emergencies? A case study of YouTube videos during the 2015-16 Zika virus pandemic. Pathog Glob Health 2018;112(6):320-8. https://doi.org/10.1080/20477724.2018.1 507784

\section{PMid:30156974}

48. Khatri P, Singh SR, Belani NK, Yeong YL, Lohan R, Wei Y, et al. YouTube as source of information on 2019 novel coronavirus outbreak: A cross-sectional study of English and Mandarin content. Travel Med Infect Dis. 2020;35:101636. https://doi. org/10.1016/j.tmaid.2020.101636

49. Qi M, Li X, Liu S, Li Y, Huang W. Impact of the COVID-19 epidemic on patterns of pregnant women's perception of threat and its relationship to mental state: A latent class analysis. PLoS One. 2020;15(10):e0239697. https://doi.org/10.1371/journal. pone.0239697

PMid:33007020

50. Yezli S, Khan A. COVID-19 pandemic: It is time to temporarily close places of worship and to suspend religious gatherings.
J Travel Med. 2020;28(2):taaa065. https://doi.org/10.1093/jtm/ taaa065

PMid:32339236

51. Al-Astewani A. To open or close? COVID-19, mosques and the role of religious authority within the British Muslim community: A socio-legal analysis. Religions. 2021;12:11. https://doi. org/10.3390/rel12010011

52. Mat NF, Edinur HA, Razab MK, Safuan S. A single mass gathering resulted in massive transmission of COVID-19 infections in Malaysia with further international spread. J Travel Med. 2020;27(3):taaa059. https://doi.org/10.1093/ $\mathrm{jtm} / \mathrm{taa} 059$

PMid:32307549

53. Harley N. British Mosque Turned into a Coronavirus Hospice to Support Efforts to Fight the Pandemic. The National; 2020. Available from: https://www.thenationalnews.com/world/britishmosque-turned-into-a-coronavirus-hospice-to-support-effortsto-fight-the-pandemic-1.1000298 [last accessed on 2021 Jul 9].

54. Ulama W. Coronavirus (COVID-19) Briefing Wifaqul Ulama (Britain); 2020. Available from: https://www.wifaqululama.co.uk/ covid19 [Last accessed on 2021 Jul 09].

55. Kowalczyk O, Roszkowski K, Montane X, Pawliszak W, Tylkowski B, Bajek A. Religion and Faith Perception in a Pandemic of COVID-19. J Relig Health. 2020;59(6):2671-7. https://doi.org/10.1007/s10943-020-01088-3

PMid:33044598

56. Koenig HG. Maintaining health and well-being by putting faith into action during the COVID-19 pandemic. J Relig Health. 2020;59(5):2205-14. https://doi.org/10.1007/ s10943-020-01035-2

PMid:32409989 